\title{
TANTANGAN DAN PELUANG PRODUK-PRODUK PROFESI PENGEMBANG TEKNOLOGI PEMBELAJARAN DI ERA DIGITAL
}

\author{
Product Challenges and Opportunities of \\ Instructional Designer in Digital Era
}

\author{
Bambang Warsita \\ Pusat Data dan Teknologi Informasi, Kementerian Pendidikan dan Kebudayaan \\ JI. RE. Martadinata, Ciputat, Tangerang Selatan, Indonesia \\ bambang.warsita@kemdikbud.go.id
}

\author{
Diterima: \\ 07 September 2019, \\ Direvisi: \\ 09 Januari 2020, \\ Disetujui: \\ 20 November 2020.
}

ABSTRAK: Profesi Pengembang Teknologi Pembelajaran (PTP) memiliki peran strategis dalam pembelajaran di era digital sekarang. Permasalahannya adalah: (1) apa produkproduk yang harus di hasilkan profesi PTP di era digital?; dan (2) bagaimana pemanfaatan dan penerapan produk PTP dalam pembelajaran di era digital? Tujuan kajian ini adalah untuk mendiskripsikan berbagai produk yang dihasilkan oleh profesi PTP, dan pemanfaatan atau penerapan produk tersebut dalam kegiatan pembelajaran di era digital sekarang. Metode penelitian yang digunakan adalah pendekatan deskriptif analitis. Pengumpulan data dilakukan melalui studi kepustakaan, yaitu menggunakan berbagai literatur dari hasil kajian dan penelitian mengenai produk-produk PTP. Hasil kajian menunjukkan bahwa profesi PTP telah menghasilkan produk-produk berupa: (1) model pembelajaran inovatif berbasis TIK; (2) konten pembelajaran dengan berbagai jenis media; dan (3) aplikasi e-pembelajaran. Kesimpulannya adalah bahwa produk-produk profesi PTP ini diharapkan dan dibutuhkan dalam menunjang terselenggaranya proses pembelajaran era digital di berbagai jenis, jenjang, dan jalur pendidikan di Indonesia. Sarannya adalah bahwa profesi PTP harus selalu meningkatkan kompetensi teknis, kreatifitas, dan inovasi untuk menghasilkan produk sesuai dengan tuntutan era digital sekarang.

Kata Kunci: Produk, Pengembang Teknologi Pembelajaran, era digital.

ABSTRAK: Instructinal Designers have strategic role in the learning of digital era. The problems are: (1) what products should Instructional Designers produce in digital era?; and (2) how are the products of Instructional Designers utilized and implemented in the learning of digital era? The objective of this study is to describe the various products that must be produced by the Instructional Designers, and their utilization or implementation in the learning of digital era. The method applied is an analytical-descriptive approach. Data collection is carried out through library research, i.e. by using literature of of study and research result on products of Instructional Designers. The study result shows that Instructional Designers 
have produced the products of: (1) ICT-based learning model innovations; (2) learning content on various types of media; and (3) e-learning applications. The conclusion is that the products of Instructional Designers are expected and needed to enhance learning process in digital era of various types, levels, as well as lines of education in Indonesia. The recommendation is that Instructional Designers must continuously improve their technical competency, creativity, and innovation to make products which are in line with the digital era challenges.

Keywords: Products, Instructional Designers, digital era.

\section{PENDAHULUAN}

Kemajuan Teknologi Informasi dan Komunikasi (TIK) telah menyentuh hampir seluruh aspek kehidupan sehari-hari manusia. Kemajuan TIK ini bahkan sering kali disebut sebagai salah satu kunci keberhasilan yang harus dikusai. Dunia pendidikan telah merasakan dampak kemajuan TIK yang telah memberikan nilai tambah atau bahkan kunci keberhasilan pelaksanaan pembelajaran. Melalui kemajuan TIK ini para guru memanfaatkan kemudahan-kemudahan dan fasilitas yang ditawarkan dalam menunjang pelaksanaan tugasnya.

Perkembangan TIK dan berkat dunia maya telah membawa budaya baru pada pembelajaran dan perubahan perilaku belajar. Cara belajar anak-anak sekarang kini telah berubah. Definisi belajar memang telah mengalami perubahan. Dulu, belajar didominasi oleh kegiatan membaca, mendengar, dan menyimak. Kini, belajar lebih banyak diekspresikan lewat interaktivitas yang sangat beragam. Seseorang yang belajar bukan hanya berinteraksi dengan guru saja, atau buku saja, melainkan berinteraksi dengan beraneka sumber belajar yang tersedia di sekitarnya tidak hanya lokal tetapi juga global (Purwanto \& Warsita, 2014). Kini, seseorang dapat belajar tanpa ketergantungan yang besar kepada guru. Orientasi belajar bergeser dari berpusat kepada guru/pendidik menjadi berpusat kepada peserta didik (student-centered learning). Mereka belajar tentang apa saja dan dengan siapa saja, bahkan yang ada di mana saja.
Belajar berbasis aneka sumber ini mendorong peserta didik untuk meningkatkan literasi informasi, meningkatkan kemampuan berpikir kritis yang sangat dibutuhkan oleh masyarakat dalam era informasi di abad 21 (Purwanto \& Warsita, 2014). Di samping itu, belajar berbasis aneka sumber lebih berpusat pada peserta didik yang memungkinkan peserta didik dapat menemukan dan membangun pengetahuan, sikap, dan perilakunya sendiri, di mana guru lebih berperan sebagai fasilitator dan manajer pembelajaran. Peserta didik memperoleh kesempatan dan fasilitas untuk membangun sendiri pengetahuannya sehingga mereka akan memperoleh pemahaman yang mendalam, dan pada akhirnya akan dapat meningkatkan kualitas dirinya.

Belajar tidak hanya dilakukan oleh dan untuk individu, melainkan oleh dan untuk kelompok, bahkan oleh organisasi secara keseluruhan. Belajar itu ada di mana saja, kapan saja, dan pada siapa saja, mengenai apa saja, dengan cara dan sumber apa saja yang sesuai dengan kondisi dan keperluan atau kebutuhan (Miarso, 2004). Belajar dapat terjadi di rumah, di sekolah, di tempat kerja, di tempat ibadah, dan di masyarakat, serta berlangsung dengan cara apa saja dan dari apa dan siapa saja. Kegiatan belajar merupakan perilaku yang kompleks, oleh karena itu telah lama menjadi obyek penelitian ilmuwan. Karena kompleksnya masalah belajar, banyak sekali teori yang berusaha untuk menjelaskan bagaimana proses belajar itu terjadi.

IImu pendidikan berkembang dengan munculnya teori baru yang mempengaruhi 
kegiatan belajar dan pembelajaran. Teori connectivism merupakan teori belajar yang menjelaskan tentang pemanfaatan teknologi internet untuk belajar dan berbagi informasi melalui website (world wide web) dan di antara pengguna internet itu sendiri. Teknologi internet ini meliputi mesin pencari web, email, wiki, forum diskusi online, jejaring sosial, youtube, serta tools lain yang dapat dimanfaatkan oleh pengguna untuk belajar dan berbagi informasi dengan orang lain. Teori connectivism mengembangkan pemahaman yang lebih dalam mengenai cara belajar dan mendapatkan pengetahuan dengan mengandalkan akses pada sumber belajar secara online (Pannen, 2016). Pembelajaran online telah berkembang pesat dalam beberapa tahun terakhir di sekolah sebagai cara belajar yang efektif untuk komunitas peserta didik online.

Tidak diragukan lagi dan telah menjadi kenyataan yang tidak dapat dipungkiri lagi bahwa TIK telah menjadi kekuatan yang mendorong perubahan dalam praktek belajar dan pembelajaran. Pemanfaatan teknologi pembelajaran dan TIK telah melebur dan memberikan arah tujuan pendidikan, yakni untuk meningkatkan hasil belajar dan memperkaya pengalaman melalui penggunaan teknologi pembelajaran yang efektif dan inovatif.

Di era yang disebut sebagai era TIK yang ditandai dengan fenomena dunia maya (cyber) ini, konsep sekolah yang tidak dibatasi oleh ruang dan waktu itu bisa sangat mudah diimplementasikan dengan memanfaatkan TIK. Misalnya cukup klik "Rumah Belajar", kita bisa dapatkan berbagai manfaat mulai dari Sumber Belajar, Laboratorium Maya, Bank Soal, Karya Komunitas, Buku Sekolah Elektronik (BSE), Kelas Maya, cara mengikuti Diklat online melalui fitur PKB (Pengembangan Keprofesian Berkelanjutan) hingga belajar tentang Peta Budaya sampai ilmu luar angkasa atau wahana Jelajah Angkasa.

Ada tiga isu strategis pendidikan di era digital, yaitu: (1) membangun akses TIK untuk memastikan pemerataan kesempatan pendidikan; (2) memanfaatkan digital education untuk meningkatkan mutu pendidikan; dan (3) menyiapkan Sumber Daya Manusia (SDM) yang berdaya saing dalam ekonomi digital (Kemkominfo, 2018).

Pengembangan dan pengintegrasian TIK ke dalam pembelajaran tersebut menjadi tugas dan tanggungjawab profesi Pengembang Teknologi Pembelajaran (PTP). Tugas pokok jabatan PTP yaitu melaksanakan kegiatan analisis dan pengkajian, perancangan, produksi, implementasi, pengendalian, dan evaluasi dalam rangka pengembangan teknologi pembelajaran (Permenpan \& RB No 28 Tahun 2017). Sedangkan, hasil kerja atau output produk yang harus dihasilkan profesi PTP dapat berupa: (1) media pembelajaran; (2) model pembelajaran; dan (3) aplikasi pembelajaran.

Media pembelajaran yang trend di era TIK atau zaman digital ini harus bisa mengoptimalkan hyper yang meliputi: (1) hypertext, yaitu lompat dari satu text ke text lain yang relevan; (2) hyperlink, yaitu lompat dari satu link ke link lain yang relevan; dan 3) hypermedia, yaitu lompat dari satu jenis media ke media lain yang relevan.

Model pembelajaran yang trend di era TIK atau zaman digital ini adalah model e-learning berbasis Massive Open Online Courses (MOOCS). E-learning berbasis MOOCS ini memiliki kelebihan dalam fleksibilitas yang memungkinkan pembelajaran dapat berlangsung tanpa kendala jarak dan waktu serta dapat dilaksanakan secara masif dengan biaya yang cenderung lebih efisien. Hasil penelitian mengenai bagaimana profil pengguna sistem e-learning berbasis MOOCs berdasarkan usia peserta perguruan tinggi (rentang usia 18-30 tahun) menunjukkan bahwa model ini berpotensi untuk meningkatkan pemerataan akses pendidikan tinggi dengan beberapa indikator, yakni: kesetaraan gender, mayoritas pengguna memiliki pendidikan terakhir SMK dan SMA/ sederajat, dan sebagian besar sudah bekerja sebagai karyawan. Adapun untuk aspek geografis, hasil analisis terhadap pengguna masih menunjukkan bahwa pengguna terkonsentrasi di Pulau Jawa (81\%) (Silvana \& Fajar, 2016). 
Implementasi model e-learning berbasis MOOCs ini memerlukan penyediaan konten atau sumber belajar digital berbasis web yang dikembangkan dalam bentuk learning object. Learning object (LO) adalah segala entitas, digital atau non-digital, yang dapat digunakan untuk pembelajaran, pendidikan atau pelatihan (Kusnandar, 2013). Penyediaan konten berbasis web dalam bentuk LO ini harus dirancang sedemikian rupa agar sesuai dengan tuntutan kurikulum. Masing-masing LO dapat disediakan dalam format media teks (modul), grafis, audio, video, multimedia, multimedia interaktif, dan hypermedia. Penyediaan konten berbasis web dalam bentuk LO dengan berbagai format media pembelajaran ini merupakan salah satu tugas profesi PTP di era digital sekarang.

Sebagai contoh, untuk mendukung implementasi Kurikulum 2013, dibutuhkan konten LO yang sangat banyak. Apabila satu Kompetensi Dasar (KD) terdiri dari rata-rata dua topik, dan masing-masing topik terdiri dari 5 indikator kompetensi, untuk setiap KD perlu dikembangkan 10 LO. Masing-masing LO dapat disediakan dalam format media sederhana, modul (media cetak), audio, video, multimedia, multimedia interaktif, dan hypermedia ( 7 jenis media). Dengan demikian, idealnya untuk satu KD harus tersedia sejumlah 70 LO dalam berbagai format media pembelajaran.

Selanjutnya, seperti pada tabel 1 berikut ini, dapat dihitung kebutuhan LO tiap mata pelajaran dan tiap jenjang, kelas dan semester. Dengan demikian, dibutuhkan konten LO yang sangat banyak. Hal ini menjadi salah satu tugas PTP untuk menyediakannya dalam memberikan layanan pembelajaran yang inovatif dan berkualitas.

Tabel 1, Kebutuhan LO

\begin{tabular}{|c|c|c|c|c|c|c|}
\hline $\bar{N}$ & $\begin{array}{c}\text { lo Jenjang } \\
\text { Pend. }\end{array}$ & $\begin{array}{l}\text { Jumlah } \\
\text { Mapel }\end{array}$ & $\begin{array}{l}\text { Jumlah } \\
\text { KD }\end{array}$ & $\begin{array}{l}\text { Jumlah } \\
\text { Topik }\end{array}$ & $\begin{array}{l}\text { Sub } \\
\text { Topik }\end{array}$ & $\begin{array}{c}\text { Jumlah } \\
\text { LO }\end{array}$ \\
\hline 1 & SD & 9 & 613 & 1.226 & 6.130 & 36.780 \\
\hline 2 & SMP & 14 & 780 & 1.560 & 7.800 & 46.800 \\
\hline 3 & SMA & 16 & 939 & 1878 & 9.390 & 56.340 \\
\hline
\end{tabular}

Sumber: Kusnandar, 2013
Berdasarkan Tabel 1 tersebut, kebutuhan LO untuk jenjang Sekolah Dasar (SD) untuk 9 mata pelajaran, dihitung mulai kelas IV, V, dan VI sebanyak 36.780. Sekolah Menengah Pertama (SMP) untuk 14 mata pelajaran kelas VII, VIII, dan IX sebanyak 46.800. Sekolah Menengah Atas (SMA) untuk 16 mata pelajaran, kelas $\mathrm{X}, \mathrm{XI}$, dan XII sebanyak 56.340. Dari perhitungan tersebut, dapat diketahui jumlah total LO yang dibutuhkan adalah sebanyak 139.920 (Kusnandar, 2013). Jumlah ini belum termasuk kebutuhan untuk Sekolah Menengah Kejuruan (SMK), kurikulum muatan lokal, serta materi pelajaran penunjang. Inilah suatu tantangan dan peluang dalam pengembangan konten atau media pembelajaran yang harus disediakan oleh profesi PTP untuk dapat berkiprah dalam pembelajaran era digital sekarang.

Berdasarkan latar belakang tersebut, fokus kajian ini adalah pada bagaimana tantangan dan peluang produk-produk profesi PTP di era digital? Adapun rumusan permasalahannya adalah: (1) apa produkproduk yang harus di hasilkan oleh profesi PTP di era digital?; dan (2) bagaimana pemanfaatan dan penerapan produk PTP di era digital?

Tujuan kajian ini adalah untuk mendiskripsikan berbagai produk yang harus dihasilkan profesi pengembang teknologi pembelajaran, dan pemanfaatan atau penerapan produk-produk tersebut dalam kegiatan pembelajaran di era digital sekarang.

\section{METODA}

Metode penelitian yang digunakan di dalam penyusunan artikel ini adalah pendekatan deskriptif analitis. Metode deskriptif bertujuan menggambarkan keadaan di lapangan melalui uraian kata-kata terkait dengan produk-produk profesi pengembang teknologi pembelajaran khususnya di era digital sekarang ini. Pengumpulan data dan informasi dilakukan melalui studi kepustakaan (library research) yaitu mengumpulkan data dari berbagai literatur baik terkait hasil kajian dan penelitian mengenai produk-produk yang dihasilkan profesi perkembang teknologi pembelajaran pada era digital sekarang. 
Selanjutnya data tersebut dianalisis dan disajikan secara deskriptif.

\section{HASIL DAN PEMBAHASAN}

Sesuai tugas dan fungsinya, Pengembang Teknologi Pembelajaran harus bisa menghasilkan produk-produk berupa: (1) model pembelajaran inovatif berbasis TIK; (2) media pembelajaran; dan (3) aplikasi epembelajaran (Kemdikbud, 2016). Produkproduk tersebut dibutuhkan dalam menunjang terselenggaranya proses pembelajaran di berbagai jenis, jenjang, dan jalur pendidikan sesuai kurikulum yang berlaku.

Instansi pengguna produk yang dihasilkan PTP antara lain adalah unit pengembangan yang ada di Kemdikbud (Pustekkom, P4TK, LPMP), Lembaga Diklat pada Kementerian dan Lembaga, Unit pengembangan yang ada di Daerah (Balai Tekkom), Perguruan Tinggi, dan Sekolah.

Adapun produk-produk yang harus dihasilkan profesi atau pejabat PTP di masa depan antara lain pada bagian berikut ini:

\section{Model Pembelajaran}

Dalam menyiapkan peserta didik untuk memperoleh peluang partisipasi dalam masyarakat global era digital, para PTP harus lebih banyak mengembangkan model-model pembelajaran berbasis tim, kolaboratif, dan memanfaatkan TIK. Pengembangan modelmodel pembelajaran berbasis TIK ini merupakan tugas pokok dan sekaligus kompetensi yang harus dimiliki PTP di era digital sekarang. Oleh karena itu, dalam memberikan layanan pembelajaran yang berkuliatas, pelaksanaan tugas PTP ini menjadi sesuatu yang harus diwujudnyatakan. Menurut Gagne (1979) dalam Suparman (2004), sistem pembelajaran adalah suatu set peristiwa yang mempengaruhi peserta didik sehingga terjadi proses belajar. Suatu set peristiwa itu mungkin digerakkan oleh guru sehingga disebut pembelajaran, mungkin digerakkan oleh peserta didik itu sendiri dengan menggunakan buku, modul, siaran televisi pendidikan, siaran radio pendidikan, multimedia pembelajaran, portal pembelajaran, e-learning, atau kombinasi dari berbagai moda pembelajaran (blended learning). Baik digerakkan oleh guru maupun peserta didik sendiri, kegiatan itu haruslah terencana secara sistematis untuk dapat disebut kegiatan pembelajaran. Oleh karena itu, bentuk nyata dari sistem pembelajaran adalah satu set bahan belajar atau strategi pembelajaran yang telah teruji secara efektif dan efisien di lapangan. Dengan kata lain, satu set peristiwa yang memfasilitasi peserta didik untuk belajar atau memudahkan peserta didik belajar.

Model pembelajaran merupakan suatu perencanaan atau suatu pola yang digunakan sebagai pedoman dalam merencanakan pembelajaran di kelas. Model pembelajaran mengacu pada pendekatan pembelajaran yang akan digunakan, termasuk di dalamnya tujuan-tujuan pembelajaran, tahap-tahap dalam kegiatan pembelajaran (sintaks), lingkungan pembelajaran, dan pengelolaan kelas (Trianto, 2010: 51).

Model pembelajaran adalah kerangka konseptual yang melukiskan prosedur sistematik dalam mengorganisasikan pengalaman belajar untuk mencapai tujuan pembelajaran tertentu dan berfungsi sebagai pedoman bagi perancang pembelajaran dan para guru dalam merancang dan melaksanakan proses pembelajaran. Model pembelajaran diartikan sebagai prosedur sistematis dalam mengorganisasikan pengalaman belajar untuk mencapai tujuan belajar (Warsita, 2014). Saat ini, telah banyak model pembelajaran yang dikembangkan dan digunakan guru, dari yang model yang sederhana sampai model yang kompleks, rumit, dan berbasis TIK.

Model pembelajaran mempunyai empat ciri khusus, yaitu: (1) rasional teoretis yang logis yang disusun oleh para pencipta atau pengembangnya; (2) landasan pemikiran tentang apa dan bagaimana peserta didik belajar (tujuan pembelajaran yang akan dicapai); (3) tingkah laku mengajar yang diperlukan agar model tersebut dapat dilaksanakan dengan berhasil; dan (4) lingkungan belajar yang diperlukan agar tujuan pembelajaran itu dapat tercapai (Budiyanto, 2016). Selain itu, model pembelajaran dapat berfungsi sebagai 
sarana komunikasi yang penting, apakah yang dibicarakan adalah tentang mengajar di kelas, atau praktik mengawasi peserta didik.

Model pembelajaran berbasis TIK yang selama ini telah dikembangkan profesi PTP meliputi model pembelajaran mikro yang diterapkan pada tingkat kelas yang keputusan penerapannya dilakukan oleh pendidik, dan model pembelajaran yang lebih makro berupa model pembelajaran yang melibatkan komponen sistem pembelajaran yang lebih banyak dan penerapannya memerlukan keputusan pembuat kebijakan. Sebagai contohnya, model pendidikan terbuka jarak jauh (SMP Terbuka, SMA Terbuka, dan Universitas Terbuka).

Pengembangan model pembelajaran didasari kebutuhan akan adaptasi dan optimalisasi terhadap teknologi yang sedang berkembang (Saripudin, 2015). Pemanfaatan teknologi digital adalah untuk memudahkan proses pembelajaran dan manajemen pengetahuan dengan prinsip belajar tidak mengenal jarak, waktu, dan tempat. Pada akhirnya, hal ini dapat meningkatkan kualitas pembelajaran.

Pada tahun 2018, Bidang Pengembangan Teknologi Pembelajaran Berbasis Multimedia dan Web Pustekkom (yang saat ini berganti nama menjadi Pusdatin) Kemdikbud mengembangkan beberapa model pembelajaran, yaitu: (1) model flipped classroom; (2) model pembelajaran discoveryinquiry; (3) model pembelajaran blended learning; (4) model pembelajaran berbasis game; dan (5) model pembelajaran Kelas Maya melalui Rumah Belajar sebagai program remedial.

Model-model pembelajaran berbasis TIK kini telah berkembang seiring dengan perkembangan IPTEK, khususnya TIK atau teknologi komputer. Berkat berkembangnya komputer dan internet kini banyak dikembangkan model pembelajaran online dan e-pembelajaran. Ada pula model pembelajaran yang mencampur penggunaan berbagai pendekatan dan media yang dikenal dengan blended learning atau hybrid learning.
Ketersediaan perangkat teknologi dan semakin mudahnya untuk pemanfaatan internet dengan bandwith yang lebar bahkan telah memungkinkan dikembangkannya model pembelajaran yang mampu melayani pendidikan terbuka dan jarak jauh secara masif dengan biaya yang cenderung lebih efisien. Model tersebut dikenal dengan Massive Open Online Courses (MOOCs), yang menjadi trend selama sepuluh tahun terakhir. Oleh karena itu, tujuan utama untuk menerapkan MOOCs adalah untuk memperluas jangkauan dan akses, selain untuk meningkatkan hasil belajar, inovasi, dan penelitian di bidang pembelajaran (Silvana \& Fajar, 2016).

Massive Open Online Courses adalah perkuliahan online yang bertujuan untuk meningkatkan partisipasi dan keterbukaan akses melalui teknologi website MOOCS yang menyediakan akses yang bebas pada bahan belajar berkualitas tinggi di mana partisipan dari seluruh dunia dapat membuat, meneliti, dan berbagi sumberdaya pendidikan terbuka (Abeer dan Miri, 2014).

Menurut Baturay (2015), MOOCS memiliki beberapa karakteristik utama, yakni keterbukaan, partisipatif, dan distributif. Partisipasi dalam MOOCS bersifat bebas dan terbuka bagi siapapun yang terkoneksi pada internet. Seorang pengguna diberikan kebebasan untuk memilih course apapun yang diminatinya tanpa ada batasan. MOOCS memiliki sifat partisipatif dalam pembuatan atau kegiatan berbagi kontribusi personal dan interaksi dengan kontributor yang memperkaya proses pembelajaran di dalamnya. Adapun partisipasi ini bersifat sukarela. Sifat distributif pada MOOCS berakar pada pendekatan connectivist di mana ilmu pengetahuan perlu didistribusikan (Silvana \& Fajar, 2016). Pembelajaran pada MOOCs berada pada lingkungan belajar sosial di mana setiap partisipan dapat berinteraksi dengan bahan ajar antarpartisipan. Bahan ajar yang tersedia biasanya hanya menjadi titik awal untuk diskusi.

Menurut Baturay (2015), aktivitas pembelajaran pada MOOCs menggunakan bentuk-bentuk berikut, yaitu: (1) video pembelajaran, biasanya dibagi menjadi 
beberapa bagian dengan durasi antara 5-10 menit; (2) penilaian, menggunakan a) penilaian otomatis dari pertanyaan pilihan ganda, dan b) penilaian peer-review di mana peserta saling menilai berdasarkan kriteria-kriteria yang ditentukan; (3) forum, di mana peserta dapat berinteraksi dengan peserta lainnya maupun dengan instruktur; (4) bacaan, yang tersedia online atau disediakan oleh instruktur; (5) sesi video langsung (live), sebagai tambahan di mana peserta dapat berinteraksi melalui video conference secara langsung dengan instruktur; dan (6) social media, di mana peserta dapat melanjutkan diskusi pada laman di platform media sosial, seperti Facebook atau Google (Silvana \& Fajar, 2016).

Inovasi di bidang pengembangan model pembelajaran yang memanfaatkan teknologi canggih tersebut dimungkinkan karena tersedianya aneka sumber belajar yang mudah diakses secara terbuka dan secara murah yaitu sumber belajar bebas akses (open educational resources atau OER).

Semua institusi pendidikan saat ini berusaha menyediakan akses terhadap sumber belajar online untuk peserta didiknya. Sekolah, lembaga Diklat, dan perguruan tinggi mengembangkan infrastruktur yang mampu menunjang terselenggaranya model pembelajaran berbasis TIK yang telah menjadi kebutuhan bagi proses pembelajaran, seperti misalnya model layanan pembelajaran di daerah Terpencil, Tertinggal, dan Terdepan (3T). Model pembelajaran ini dalam bentuk Pusat Sumber Belajar berbasis TIK di sekolah pada daerah terpencil, tertinggal, dan terdepan (PSB berbasis TIK di daerah 3T). Pengembangan dilakukan berdasarkan konsep pembelajaran modern (pembelajaran abad 21), pemberdayaan, tumbuh dari bawah, dan kemitraan, serta dengan belajar dari pengalaman negara lain (Kusnandar, 2013). Untuk mendukung layanan pembelajaran tersebut, masing-masing sekolah diberikan paket bantuan PSB lengkap yang terdiri dari pembangkit listrik tenaga surya, antena parabola, pesawat televisi, 6 unit laptop, modem, wi-fi, dan sebuah harddisk satu terabyte berisi konten bahan belajar digital. Berbagai model pembelajaran inovatif berbasis TIK tersebut merupakan karya atau output kegiatan profesi atau pejabat PTP. Dengan kata lain, profesi PTP ke depan harus bisa menghasilkan model-model pembelajaran inovatif berbasis TIK berdasarkan kurikulum yang berlaku sesuai dengan jenis, jalur, dan jenjang pendidikan.

\section{Media Pembelajaran}

Sesuai konsep teknologi pembelajaran, pengembangan media pembelajaran menggunakan prinsip-prinsip pengembangan desain instruksional. Maksudnya, produk media yang dihasilkan diharapkan akan terjamin kualitasnya dan dapat memenuhi fungsinya sebagai sumber belajar untuk mencapai kompetensi atau tujuan pembelajaran yang telah ditetapkan.

Pengembangan media pembelajaran ini dapat melalui langkah-langkah yang sistematis sebagai berikut: (1) di mulai dengan penyusunan Garis-garis Besar Isi Media (GBIM) yang paling lazim dan tepat melalui lokakarya (workshop); (2) penulisan naskah media (cetak, audio, dan video) dan pengkajian ahli materi (expert review), ahli media, dan desain instruksional; (3) produksi media pembelajaran (cetak, audio, dan video) melalui tahap persiapan (script conference), kegiatan produksi dan penyelesaian seperti editing, preview, revisi; (4) evaluasi media pembelajaran melalui reviu ahli, reviu kelompok kecil, dan uji coba lapangan, kemudian diperbaiki (revisi) dan dinyatakan final atau layak dimanfaatkan (Warsita, 2012); dan (5) penggandaan dan pendistribusian media pembelajaran ke peserta didik.

Pengembangan media pembelajaran yang menjadi tugas jabatan PTP meliputi jenis media sederhana, modul (media cetak), audio, video, multimedia, multimedia interaktif, dan hypermedia pembelajaran (Permenpan \& RB No 28 Tahun 2017). Namun, dalam perkembangan TIK dan tuntutan kebutuhan, perlu mengembangkan media pembelajaran berbasis web karena memungkinkan penggunaan konten yang lebih variatif, mulai dari buku elektronik (e-book), video pembelajaran, podcast, multimedia interaktif hingga penggunaan hypermedia pembelajaran. 
Para PTP yang mengembangkan media pembelajaran ini perlu memiliki serangkaian kemampuan kreativitas, baik berpikir kreatif maupun sikap kreatif. Selain itu, pengetahuan yang harus dikuasai para PTP dalam mengembangkan media pembelajaran adalah pengetahuan tentang media pembelajaran itu sendiri, pengetahuan tentang analisis kebutuhan, perancangan (jabaran materi, penyusunan GBIM, teknik penulisan naskah), dan pengetahuan tentang pelaksanaan teknis produksi serta evaluasi (Warsita, 2012). Oleh karena itu, PTP harus memiliki kompetensi teknis dalam mengembangkan media pembelajaran. Bahkan perlu menumbuh-kembangkan dan memberdayakan kreativitas para PTP dalam mengembangkan media pembelajaran. Akhirnya, dapat dihasilkan media pembelajaran yang berkualitas secara teknis, menarik, dan sesuai dengan kebutuhan sasaran/peserta didik.

PTP selama ini telah menghasilkan produk media pembelajaran yang beraneka ragam, mulai dari media pembelajaran sederhana, cetak, audio, audio-visual/video sampai dengan multimedia, multimedia interaktif, dan hypermedia. Berbagai jenis dan bentuk media pembelajaran yang bisa dikategorikan menjadi beberapa kelompok tersebut sampai sekarang ini masih banyak dikembangkan karena memang diperlukan untuk menunjang proses pembelajaran.

Sebagai contoh, dalam rangka untuk meningkatkan jumlah media pembelajaran atau konten/bahan belajar berbasis TIK, pada tahun 2018 Pustekkom (yang sekarang berubah namanya menjadi Pusdatin) Kemdikbud melalui Bidang Pengembangan Teknologi Pembelajaran Berbasis Multimedia dan Web menyelenggarakan kegiatan lomba membaTIK (Membuat Bahan Ajar Berbasis TIK) yang dapat diakses melalui web: http:// membatik.kemdikbud.go.id. MembaTIK ini merupakan kompetisi dalam membuat media pembelajaran berbasis TIK oleh guru-guru dari berbagai jenjang pendidikan mulai dari SD, SMP, SMA dan SMK. Melalui MembaTIK, diharapkan guru-guru dapat membuat media pembelajaran atau bahan belajar berbasis TIK yang menarik, kreatif, dan interaktif yang dapat digunakan dalam kegiatan pembelajaran sehari-hari di sekolah. Lomba membaTIK ini diadakan untuk mendorong masyarakat dari berbagai profesi khususnya para PTP dan guru untuk membuat media pembelajaran atau bahan belajar berbasis TIK yang menarik dan berkualitas.

Media pembelajaran atau bahan ajar berbasis TIK ini dapat menggunakan berbagai format teknologi, yaitu: (1) video pembelajaran yaitu dalam format mp4; (2) media presentasi power point (ppt, pptx); dan (3) multimedia interaktif yaitu bisa berupa animasi, adobe animate (swf), HTML5, javascript, exe dll. Dalam lomba membaTIK ini tercatat ada 2.830 pendaftar dan hanya 690 peserta yang mengunggah karya media atau konten pembelajaran dari 5 (lima) kategori yaitu 135 karya dari jenjang SD/MI/sederajat, 133 karya dari SMP/MTs/sederajat, 146 karya dari SMA/ sederajat, 117 karya dari SMK/sederajat, dan 12 konten budaya. Jadi, dari 2.830 pendaftar, hanya 690 orang yang mengirimkan karya, dengan demikian ada 2.140 orang tidak melanjutkan untuk mengikuti lomba dengan berbagai alasan, seperti misalnya tidak punya ide, tidak punya bahan, dan lain lain (Warsita, 2018). Oleh karena itu, sudah diantisipasi panitia dengan menyediakan beberapa buku panduan dalam pengembangan bahan ajar berbasis multimedia dan web, dan menyediakan video tips untuk membantu peserta mengatasi kesulitan dalam mengikuti membaTIK, bahkan supaya membaTIK-nya jadi bagus dan menarik.

Dewasa ini berkembang jenis media baru yang dikenal sebagai obyek pembelajaran digital (Digital Learning Object atau DLO). Objek pembelajaran adalah sembarang entitas yang dapat digunakan sebagai bahan pembelajaran maupun pelatihan (Dirjen Dikti, 2014). Oleh karena itu, bahan-bahan pembelajaran konvensional (misalnya: modul, lembar kerja, handout, diktat, peta, dan sebagainya) dapat disebut sebagai objek pembelajaran. Istilah objek pembelajaran sendiri baru populer seiring dengan popularitas pembelajaran berbasis teknologi (komputer, dan kemudian Internet). Pada pembelajaran online atau pembelajaran berbasis Internet, objek pembelajaran dapat 
berupa teks, grafis, gambar, suara, video, maupun multimedia.

Berbagai jenis media pembelajaran seperti misalnya media sederhana, modul, audio, video, multimedia, multimedia interaktif, dan hypermedia pembelajaran ini diperlukan oleh peserta didik di semua jenis, jalur, dan jenjang pendidikan. Sebagai contoh, portal Rumah Belajar pada fitur sumber belajar harus menyediakan bahan belajar atau konten digital dalam bentuk LO dengan jumlah sangat banyak. Secara kuantitas, jumlah konten LO yang harus tersedia di Rumah Belajar untuk mendukung penerapan kurikulum 2013 sangat banyak. Misalnya apabila satu satuan pendidikan dengan satu kelas dan satu mata pelajaran ini memiliki satu Kompetensi Dasar (KD) yang terdiri dari rata-rata dua topik, dan masing-masing topik terdiri dari 5 indikator kompetensi, untuk setiap KD perlu dikembangkan 10 LO. Masing-masing LO dapat disediakan dalam format media teks, grafis, audio, video, animasi, dan simulasi (6 jenis media). Dengan demikian, idealnya untuk satu KD tersedia sejumlah 60 LO dalam berbagai format media.

Selanjutnya, dapat dihitung kebutuhan LO setiap mata pelajaran dan setiap jenjang, kelas dan semester. Sebagai gambaran, Tabel 2 berikut menyajikan data kebutuhan konten digital untuk Sumber Belajar pada portal Rumah Belajar.

Tabel 2, Jumlah Kebutuhan Konten Fitur Sumber Belajar Portal Rumah Belajar Sesuai Kurikulum 2013 (K13)

\begin{tabular}{|c|c|c|c|c|c|c|}
\hline Jenjang & Kelas & $\begin{array}{l}\text { Jml } \\
\text { Mapel }\end{array}$ & $\begin{array}{c}\mathrm{Jml} \\
\mathrm{KD}\end{array}$ & $\begin{array}{l}\text { Jml } \\
\text { Topik }\end{array}$ & $\begin{array}{l}\text { Jml } \\
\text { Indi } \\
\text { kator }\end{array}$ & $\begin{array}{c}\text { Jml } \\
\text { LO }\end{array}$ \\
\hline & & 1 & 1 & 5 & 5 & 3 \\
\hline \multirow[t]{6}{*}{ SD } & 1 & 6 & 53 & 265 & 1.325 & 3.975 \\
\hline & 2 & 6 & 52 & 260 & 1.300 & 3.900 \\
\hline & 3 & 6 & 54 & 270 & 1.350 & 4.050 \\
\hline & 4 & 8 & 73 & 365 & 1.825 & 5.475 \\
\hline & 5 & 8 & 65 & 325 & 1.625 & 4.875 \\
\hline & 6 & 8 & 61 & 305 & 1.525 & 4.575 \\
\hline \multirow[t]{3}{*}{ SMP } & 7 & 10 & 116 & 580 & 2.900 & 8.700 \\
\hline & 8 & 10 & 121 & 605 & 3.025 & 9.075 \\
\hline & 9 & 10 & 109 & 545 & 2.725 & 8.175 \\
\hline \multirow[t]{3}{*}{ SMA } & 10 & 16 & 157 & 785 & 3.925 & 11.775 \\
\hline & 11 & 16 & 182 & 910 & 4.550 & 13.650 \\
\hline & 12 & 16 & 142 & 710 & 3.550 & 10.650 \\
\hline
\end{tabular}

Melihat jumlah kebutuhan LO yang banyak dan tuntutan inovasi pembelajaran, pengembangan konten digital akan lebih baik apabila dilakukan secara bersama-sama. Pengembangan LO seyogyanya menjadi pekerjaan bersama yang melibatkan bergai profesi, yaitu para guru, para PTP, widyaiswara, dosen, dan para penggiat media pembelajaran. Untuk kelancaran kolaborasi dan sinergi antarprofesi ini diperlukan kesepakatan-kesepakatan bersama, antara lain menyangkut target bersama, standardisasi, dan apresiasi.

Produk PTP berupa konten digital dalam berbagai format media pembelajaran tersebut selanjutnya disebarluaskan melalui berbagai saluran komunikasi dan teknologi jaringan termasuk internet. Saat ini, produk media pembelajaran umumnya disimpan dalam suatu server berupa cloud computing, dan dapat diakses dan dimanfaatkan oleh penggunanya secara terbuka. Sumber belajar yang dapat dimanfaatkan secara bebas tersebut disebut Open Educational Resources (OER), misalnya Indonesian Open Educational Resources (Indonesian OERHub) yang dapat diakses dilaman: http:// rumahbelajar.id/. Indonesian OER-Hub adalah platform yang dilengkapi dengan berbagai konten digital yang terkait dengan pendidikan dan budaya yang dapat diakses secara online oleh semua orang di kawasan Asia Tenggara dan sekitarnya. OER bertujuan untuk membuka potensi untuk akses yang lebih efektif, rata, dan inklusif, di mana setiap orang dimungkinkan mengakses materi OER di manapun dan kapanpun termasuk orangorang dengan disabilitas, marginal, dan kelompok terpinggirkan.

Salah satu platform teknologi pembelajaran yang berbasis siaran (broadcast) dapat melalui siaran radio dan siaran TV. Ada dua mainstream yang dikerjakan profesi PTP, yaitu web-based dan broadcast-based. Intinya, PTP harus mampu berkarya untuk menyambungkan ruang kelas dan rumah tinggal untuk belajar. Artinya, peserta didik bisa belajar melalui media radio atau TV. Oleh karena itu, PTP harus mampu mengembangkan siaran radio dan siaran TV untuk pembelajaran. Kegiatan belajar di 
rumah misalnya adalah mengulang materi pelajaran, mengerjakan $\mathrm{PR}$, dan mengerjakan proyek/tugas. Dalam kegiatan belajar di rumah ini, peserta didik dapat menonton televisi edukasi untuk menunjang pembelajaran mereka, demi menghindari tontonan dari TV swasta yang tidak mendidik. Terkait dengan tugas PTP, bagaimana menyajikan tayangan TV agar menarik dan masih dalam lingkup pembelajaran? Dengan strategi produksi dan penyiaran: (a) produksi dapat dilakukan oleh: Pustekkom, guru, siswa, komunitas, pengembang media pembelajaran. Program masa depan adalah mendorong agar produksi konten berbasis lokal (contextualize content), berbasis komunitas di mana proses pembelajaran dilaksanakan; (b) penyiaran, dilakukan melalui: satelit, streaming, kerjasama TV lokal/ daerah, penyebaran konvensional memanfaatkan external hardisk atau CD. Oleh karena itu, perlu dipertimbangkan strategi mengembangkan konten yang size-nya tidak terlalu besar sehingga dapat diunduh dengan cepat dan mudah.

\section{Aplikasi e-Pembelajaran}

Pendayagunaan atau pemanfaatan TIK dalam pembelajaran memerlukan tersedianya perangkat keras (hardware) dan perangkat lunak (software). Artinya, hardware bisa digunakan apabila tersedia software di dalamnya, demikian pula sebaliknya software akan bisa dimanfaatkan apabila tersedia hardware yang menjalankannya. Software meliputi tiga jenis, yaitu software operating sistem (OS), software aplikasi, dan software data atau konten. Software OS adalah software yang berfungsi sebagai sistem operasi, seperti DOS, Windows, Linux, dan Unix. Aplikasi adalah software yang digunakan untuk membangun atau menjalankan proses sesuai dengan perintah-perintah pemrograman, misalnya office, Learning Management System (LMS), dan lain-lain. Sedangkan data atau bahan belajar termasuk ke dalam kelompok software konten, misalnya sistem manajemen konten atau Content Management System (CMS). Adapun contoh CMS berbasis web dengan lisensi open source adalah content management system wordpress.

Aplikasi adalah perangkat lunak komputer untuk keperluan pembelajaran. ePembelajaran adalah proses layanan pembelajaran dengan berbasis elektronik dalam bentuk audio, video dan multimedia yang didistribusikan melalui radio, televisi, komputer, intranet, dan internet (Pasal 1 Permendikbud No. 99 Tahun 2013). Dengan demikian, aplikasi e-pembelajaran merupakan sebuah perangkat lunak komputer untuk keperluan proses layanan pembelajaran dengan berbasis elektronik dalam bentuk audio, video dan multimedia yang didistribusikan melalui radio, televisi, komputer, intranet, dan internet untuk mencapai hasil pembelajaran yang efektif.

PTP juga menghasilkan produk berupa perangkat aplikasi yang dimanfaatkan untuk pembelajaran berbasis TIK atau epembelajaran. Aplikasi atau perangkat lunak (software) tersebut dikembangkan sesuai kebutuhan dan dirancang dalam berbagai bentuk untuk tujuan mengelola konten pembelajaran atau untuk mengelola pembelajaran online. Kebutuhan akan aplikasi pembelajaran ini berkembang karena ketersediaan perangkat teknologi (devices) yang semakin beraneka ragam dan semakin banyak digunakan, seperti tablet, ipad, dan mobile devices lainnya.

Selain itu, berkembang dan semakin banyaknya perangkat teknologi pembelajaran yang tersedia di sekolah juga membutuhkan aplikasi e-pembelajaran yang semakin beragam. Sebagai contoh, untuk pemanfaatan perangkat komputer yang tersedia di sekolah diperlukan berbagai jenis aplikasi e-pembelajaran. Guna mengoptimalkan penggunaan papan tulis interaktif (interactive withboard) diperlukan aplikasi epembelajaran. Kepemilikan laptop yang semakin tinggi juga dapat dimanfaatkan untuk mengembangkan model aplikasi pembelajaran menggunakan games (game-based learning) (Kemdikbud, 2016).

Dalam pelaksanaan tugas dan fungsi tersebut, profesi atau pejabat PTP perlu bekerjasama dengan profesi lain misalnya guru, dosen, widyaiswara, pranata komputer, dan lain lain untuk: (1) mengembangkan dan 
menerapkan model-model pembelajaran inovatif berbasis TIK; (2) mengembangkan dan menggunakan berbagai media dan sumber belajar berbasis TIK; dan (3) mengembangkan dan memanfaatkan aplikasi e-pembelajaran (e-learning).

Ragam model bisnis penyedia aplikasi pendidikan, yaitu: (1) platform e-learning untuk masyarakat umum, misalnya Kelaskita (kelaskita.com), HarukaEdu (harukaedu. com), Kelase (kelase.com); (2) konten edukasi dalam bentuk video, misalnya Quipper (quipper.com), Zenius (zenius.net); (3) pengelolaan kegiatan belajar mengajar di sekolah, contohnya Quintal (quintal.id), AIMSIS (aimsis.com); (4) menghubungkan pengguna dengan guru les/kursus/pelatihan, contohnya Sukawu (sukawu.com), PrivatQ (privatq.co.id); (5) platform yang menggabungkan berbagai fungsi, contohnya Ruang Guru (bimbel.ruangguru.com atau ruangguru.com), Extramarks Indonesia (extramarks.id) (Kemkominfo, 2018); (6) layanan belajar bahasa Inggris online, misalnya bahaso (bahaso.com), Squline (youngster.id); dan (7) Pustekkom Kemdikbud mengembangkan platform situs/aplikasi pembelajaran online rumah belajar (belajar.kemdikbud.go.id).

\section{Pemanfaatan dan Penerapan Produk PTP}

Kesempatan untuk memanfaatkan media produk PTP sekarang ini semakin terbuka lebar. Berkat perkembangan teknologi komputer dan internet, tersedia ruang maya seperti Open Educational Resources (OER), dan bisa pula media disalurkan melalui berbagai perangkat teknologi pembelajaran yang kini semakin beragam, seperti perangkat mobile, tablet dan lain-lain. Misalnya, Indonesian OER-Hub di laman: http:// rumahbelajar.id/ ini kontributor konten digitalnya berasal dari berbagai instansi pengguna PTP, seperti: Pustekkom, BPMTPK Surabaya, BPMRPK Yogyakarta, BPMPK Semarang, PPPPTK Bidang Bahasa, dan sebagainya.

Sementara itu, untuk penerapan model pembelajaran, kesempatan juga sangat terbuka untuk melayani kebutuhan di berbagai jenis, jenjang, dan jalur pendidikan. Kini, di lembaga Diklat sedang giat mengembangkan online learning dan model pembelajaran moda kombinasi (blended learning) atau model pembelajaran jarak jauh lainnya.

Di Era Digital bisa dikatakan bahwa peserta didik yang berupaya untuk menciptakan pengetahuan baru dalam proses konstruksi, dan mereka membutuhkan daya dukung yang kuat untuk bisa berkreasi dengan maksimal. Daya dukung itu adalah lingkungan belajar, media pembelajaran, termasuk media digital, sumber belajar, termasuk sumber-sumber informasi di internet (Doringin, 2016) dan aplikasi pembelajaran. Artinya, media dan aplikasi pembelajaran sebagai karya profesi PTP ini sangat ditunggu-tunggu guru oleh peserta didik.

Adapun efektivitas implementasi model pembelajaran e-learning misalnya hasil survei Bimbel online terbesar di Indonesia menunjukkan: 1) tingkat kepuasan pengguna mencapai 93\%; 2) pembelajarannya lebih menarik dibanding pembelajaran di sekolah $96 \%$; 3) sangat membantu pemahaman konsep 98\%; 4) sangat membantu persiapan ujian98\% (https://bimbel.ruangguru.com). Oleh karena itu, penerapan modep pembelajaran e-learning ini sanagat dipengaruhi beberapa faktor-faktor seperti faktor teknologi, pedagogi, dan individu yang harus diperhatikan.

Akhirnya, agar produk-produk PTP dapat diterapkan dan dimanfaatkan di berbagai jenis/jalur/jenjang pendidikan, jabatan PTP dapat diangkat dan berkedudukan di unit kerja/instansi Pemerintah Pusat atau Pemerintah Daerah yang memiliki fungsi: (1) pengembangan inovasi/aktivitas pembelajaran; (2) pendidikan dan pelatihan; (3) pendidikan dan pembelajaran jarak jauh; (4) bimbingan teknis di bidang pembelajaran; (5) layanan bantuan pembelajaran; (6) penjaminan mutu/kualitas pembelajaran; (7) peningkatan mutu/kualitas pembelajaran; (8) pengembangan model dan media pembelajaran; (9) pemanfaatan model dan media pembelajaran; dan (10) pendayagunaan Teknologi Informasi dan Komunikasi (TIK) untuk pembelajaran (Permendikbud No 13 Th 2017). 


\section{SIMPULAN DAN SARAN}

\section{Simpulan}

Berdasarkan analisis dan pembahasan di atas, profesi PTP harus dapat menghasilakan produk-produk berupa: (1) model pembelajaran inovatif berbasis TIK; (2) media pembelajaran dalam berbagai jenis media dan pilihan teknologinya; dan (3) aplikasi epembelajaran. Produk-produk profesi PTP ini ditunggu dan dibutuhkan dalam menunjang terselenggaranya proses pembelajaran di berbagai jenis, jenjang, dan jalur pendidikan di era digital sekarang.

Implementasi model-model pembelajaran berbasis TIK atau model-model epembelajaran ini menuntut tersedianya berbagai konten dalam berbagai jenis media pembelajaran dan dukungan aplikasi epembelajaran yang kuat dan handal. Tersedianya berbagai model e-pembelajaran, konten dengan berbagai jenis media, dan aplikasi e-pembelajaran ini merupakan tugas profesi PTP untuk menghasilkan karya atau produknya. Tersedianya berbagai produk PTP ini merupakan tuntutan dan kebutuhan pembelajaran di era digital untuk semua jalur/ jenis/jenjang pendidikan.

\section{Saran}

Profesi PTP harus kreatif dan inovatif untuk menghasilkan produknya sesuai dengan tuntutan pembelajaran era digital sekarang. Selain itu, profesi PTP harus selalu meningkatkan kompetensi teknis agar dapat menghasilkan produknya sesuai tuntutan teknologi digital sekarang ini dan masa depan.

\section{PUSTAKA ACUAN}

\section{Buku}

Budiyanto, M. Agus Krisno. (2016). Sintaks 45 Metode Pembelajaran dalam Student Centered Learning (SCL), Malang: Penerbitan Universitas Muhammadiyah Malang.

Bilfaqih, Y., Qomarudin, M.N. (2015). Esensi Pengembangan Pembelajaran Daring Pandung Berstandar Pengembanagan Pembelajaran Daring untuk Pendidikan dan Pelatihan, Yogyakarta: Penerbit Deepublish.
Miarso, Y. (2004). Menyemai Benih Teknologi Pendidikan, Jakarta: Prenada Media.

Trianto. (2010). Model Pembelajaran Terpadu dalam Teori dan Praktek. Surabaya: Pustaka IImu.

\section{Jurnal/Prosiding/Disertasi/Tesis/Skripsi}

Abeer, W. \& Miri, B. (2014). Students' Preferences and Views about Learning in MOOCs. Procedia-Social and Behavioral Sciences. vol. 152, 318-323.

Kusnandar. (2013). Pengembangan Bahan Belajar Digital Learning Object. Jurnal Teknodik. Vol. 17, Nomor 1, Maret 2013.

Saripudin. (2015). Pengembangan Model Pembelajaran Abad 21 dengan Menggunakan Teknologi Web 2.0. Jurnal Teknodik. Volume 19 Nomor 1, April 2015.

Silvana, Hana \& Fajar, Yuniar. (2016). Analisis Pengguna Terhadap Sistem E-Learning Berbasis Massive Open Online Courses (Moocs) dalam Pemerataan Akses Pendidikan Pada Jenjang Perguruan Tinggi. Jurnal Edutech. Tahun 15, Vol. 15, No. 2, Juni 2016 hal. 170-187.

Sitorus, E.S. (2015). Analisis Kualitas E-Learning dengan Menggunakan ISO/IEC 1976-1 (Studi Kasus: I-Caring). E-Proceeding of Engineering. Vol. 2 No. 1 April 2015.

Warsita, B. (2012). Kreativitas Dalam Pengembangan Media Video/Televisi Pembelajaran. Jurnal Teknodik. Vol. 16 No. 1, Maret 2012.

\section{Lain-lain}

Doringin, Ferry. (2016). Guru Di Era Digital. https:/ /pgsd.binus.ac.id/2016/05/04/guru-di-eradigital/, diakses pada tanggal 6 September 2019.

Goldberg, John dan Louis Markoczy. (2017). Complex Rhetoric and Simple Games. [online], Cranfield University, http: // www.Cranfield.ac.za/public/cc/cc047/papers/ complex/html/complex.html, diakses pada tanggal 30 Agustus 2017.

Kemdikbud. (2016). Naskah Akademik Usul Perubahan Permenpan Jabatan Fungsional PTP. Jakarta: Kementerian Pendidikan dan Kebudayaan. 
Kemdikbud. (2013). Permendikbud No. 99 Tahun 2013 tentang Tata Kelola Teknologi Informasi dan Komunikasi di Lingkungan Kementerian Pendidikan dan Kebudayaan. Jakarta: Kemdikbud.

Kemdikbud. (2017). Permendibud No. 13 Tahun 2017 tentang Pedoman Formasi Jabatan Fungsional Pengembang Teknologi Pembelajaran. Jakarta: Kemdikbud.

Kemkominfo. (2018). Paparan Menteri Komunikasi dan Informatika pada Rembug Nasional Pendidikan Kebudayaan. Jakarta, 6 Februari 2018.

Kemenristekdikti. (2019). Panduang Proses Pembelajaran Daring SPADA 2019. Jakarta: Direktorat Pembelajaran, Ditjen Pembelajaran dan Kemahasiswaan.

Menpan. (2017). Peraturan Menteri Negara Pendayagunaan Aparatur Negara dan Reformasi Birokrasi Nomor 28 Tahun 2017 tentang Jabatan Fungsional Pengembang Teknologi Pembelajaran.
Pannen, Paulina. (2016). Peran Instructional Design: Sekarang dan Masa Depan. Jakarta: Materi Simposium Pengembang Teknologi Pembelajaran, 29 sd 31 Maret 2016.

Purwanto, \& Warsita, B. (2014). Belajar dan Pembelajaran. Jakarta: Pustekkom Kemdikbud, Modul Pelatihan.

Warsita, B. (2018). Evaluasi Kelayakan Konten Berbasis Multimedia dan Web. Jakarta: Pustekkom Kemdikbud, Laporan Kegiatan tidak dipublikasikan.

Web lomba MembaTIK: http:// membatik.kemdikbud.go.id. diakses pada 6 September 2019.

OER HUB. Teach what you learn, Share what you have, http://rumahbelajar.id/ diakses pada 5 September 2019.

Kenapa Harus Memilih ruang belajar? https:// bimbel.ruangguru.com pada 6 September 2019. 
